\title{
Notes on some rare polypores, found in Russia 2. Junghuhnia vitellina sp. nova, plus genera Cinereomyces and Skeletocutis
}

\author{
WJACHESLAV A. SPIRIN
}

\begin{abstract}
SPIRIN, W.A. 2005: Notes on some rare polypores, found in Russia 2. Junghuhnia vitellina sp. nova, plus genera Cinereomyces and Skeletocutis. - Karstenia 45: 103-113. Helsinki. ISSN 0453-3402.

A new species Junghuhnia vitellina Spirin is described, growing on Betula mandshurica in Russian Far East. Cinereomyces lenis (P. Karst.) Spirin, comb. nova is a so-called kelo fungus; its closest relative $C$. vulgaris (Fr.) Spirin, comb. nova has relatively wide set of hosts. The latter is new to Russia. Eleven species of Skeletocutis are discussed, and some data on their ecology are treated. S. chrysella Niemelä, S. subincarnata (Peck) Jean Keller and S. stellae (Pilát) Jean Keller are rare taiga species, growing on large spruce or pine trunks at late stages of wood-decomposition. S. biguttulata (Romell) Niemelä and $S$. brevispora Niemelä are locally common and found in both southern and northern parts of the study area. S. carneogrisea David and S. kuehneri David grow in association with Trichaptum species in virgin as well as managed coniferous forests. S. albocremea David is very rare; it was collected only once in old pine forest. S. kuehneri and S. papyracea David are new to Belarus.
\end{abstract}

Key words: Cinereomyces, ecology, Junghuhnia, polypores, rare species, Skeletocutis, taxonomy, wood-rotting fungi

Wjacheslav A. Spirin, St. Petersburg University of Humanities, Fuchika 15, 192238

St. Petersburg, Russia

\section{Introduction}

Skeletocutis Kotl. \& Pouzar is a taxonomically difficult genus of polypores. After the studies on genus and species limits (Keller 1979, David 1982, Niemelä \& Dai 1997, Niemelä 1998), there is a need of supplementary floristic and ecological information. Bondartseva (1998) gave data on seven species of Skeletocutis found in Russia; at present the number is approaching twenty only in the European part of the country (Niemelä 2001, Niemelä et al. 2001, Lindgren 2001, Zmitrovich 2003).

This paper deals with morphology and ecology of 13 species included within this genus till the moment. It is evident that many species of the genus are very close to the core of Tyromy- ces $\mathrm{P}$. Karst. s. str., and could be combined into it (Niemelä 1998, Kotiranta \& Penzina 2001). However, a few species (the Skeletocutis lenis complex) maintain some features, which link them with the genus Cinereomyces Jülich.

Most of the recent species in Skeletocutis have been defined after materials from either Mediterranean area or Boreal Northern Hemisphere (David 1982, Niemelä 1985b, 1998). Hence a study carried out in areas with more continental climate (European Russia) provides new information on morphological variability and ecological preferences of the recently described or poorly known Skeletocutis species.

A new species Junghuhnia vitellina Spirin is also described and illustrated in this paper. 


\section{Material and methods}

The microscopic characters were studied with Karl Zeissamplival microscope. The chemical reagents used in the microscopic examination were $5 \%$ solution of potassium hydroxide $(\mathrm{KOH})$, Melzer's reagent (IKI) and Cotton Blue (CB). A total of 30 spores from each specimen were measured with an oil immersion objective. For presenting a variation of spore size, $5 \%$ of measurements have been excluded from each end of the range, and are given in parentheses.

\section{Study area}

Nizhny Novgorod (until 1991 Gorky) Region is situated in European Russia, between the latitudes $54^{\circ}$ and $58^{\circ} \mathrm{N}$, ranging about $75000 \mathrm{~km}^{2}$. The area is diivided by rivers Oka and Volga. The climate is moderately continental; the growing season is $130-170$ days, and does not change essentially from south to north (Kuznetsov 1974); therefore many broad-leaved trees (i.e. Quercus robur, Acer platanoides, Tilia cordata, Ulmus spp.) dominating in southern half of area spread along the rivers further to north. The limits of vegetation zones are unclear, and changes in the vegetation do not follow any regular pattern
(Averkiev 1954). For example, the lack of oak in some northern parts of the study area is caused by anthropogenic rather than climatic factors. Most village buildings in the area are made from logs of two-hundred-year old oak trees (A. Shirokov, pers. comm.).

The administrative division of Nizhny Novgorod Region and study sites are shown in Fig. 1 . The numbers of study sites are given in parentheses below, after the descriptions of their plant associations.

Old-growth oak forests are characterized by tree stands consisting of very old (150-250 years) oaks (Quercus robur). Linden (Tilia cordata), maple (Acer platanoides), ash (Fraxinus excelsior), elm (Ulmus glabra) and hazel (Corylus avellana) are present, too. Herbaceous cover is not very diverse, and consists of Aegopodium podagraria in moderately moist forests $(2,7)$, and Carex pilosa and Asperula odorata in more dry ones (1). In northern part of the area, oak forests are observed only along the rivers, and elm and hazel are absent there (10).

Old-growth pine-spruce forests have developed on rich carbonate soils, and so the tree layer is fairly complicated, composed of pine (Pinus sylvestris) and/or spruce (Picea abies) together with oak, linden and aspen (Populus tremula). Field layer consists of Aegopodium podagraria, Stellaria holostea, Pulmonaria obscura, Actaea

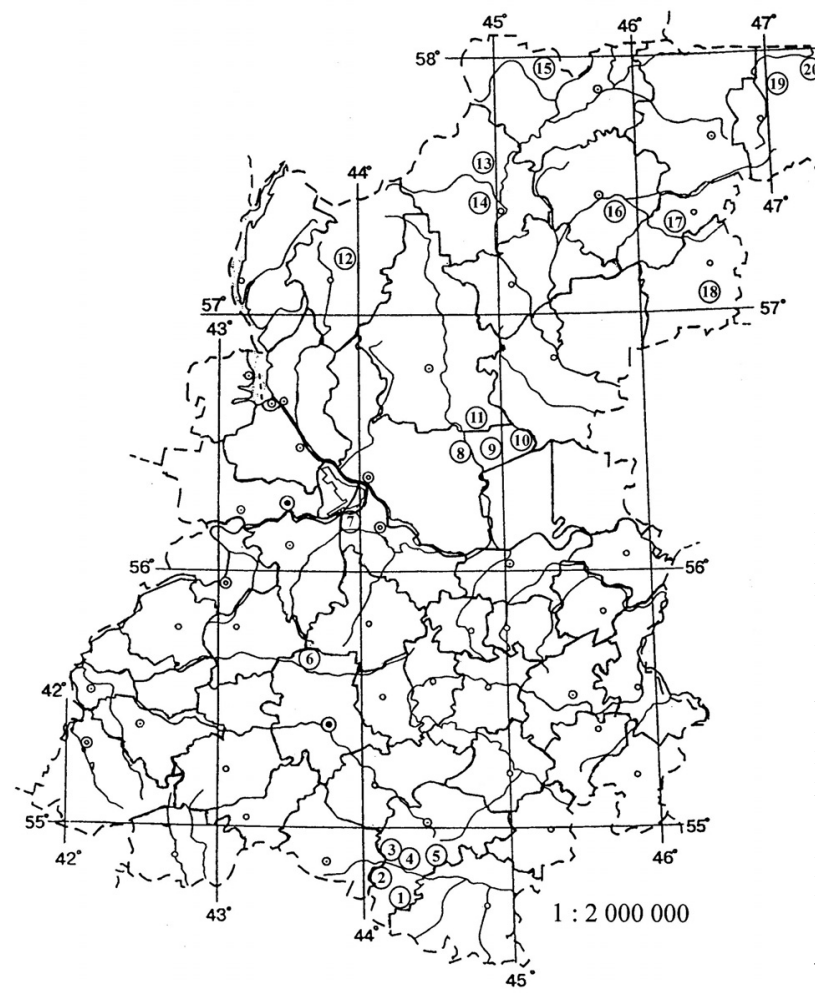

Fig.1. Administrative division of Nizhny Novgorod Region. Study places are marked with dots and numbers. Lukoyanov District: 1 - Pavlovka; 2 Sanki; 3, 4-Razino; 5 - Panzelka. Arzamas District: 6 - Pustynsky Reserve. Nizhny Novgorod City: 7 - Botanical Garden of Nizhny Novgorod University. Bor District: 8, 9, 10 - Kerzhensky Reserve. Semyonov District: 11 - Kerzhensky Reserve. Kovernino District: 12 - Belbazh. Varnavino District: 13 - Shudskoye forestry; 14 - Lapshanga. Vetluga District: 15 - Klenovik Reserve. Uren' District: 16 - Vaya. Tonkino District: 17 - Tonkinsky Reserve. Sharanga district: 18 - Kilemarsky Reserve. Tonshaevo District: 19 - Pizhemsky Reserve; 20 - Burepolom. 
spicata, Carex pilosa, Asarum europaeum, and Oxalis acetosella $(\mathbf{3}, \mathbf{5}, \mathbf{6}, \mathbf{8 , 9})$. Average age of coniferous trees is $120-220$ years.

Old aspen and birch forests are the communities that have replaced old-growth spruce forests as a result of selective cutting. Birch (Betula spp.), aspen and linden dominate within the tree stand; solitarily standing and fallen spruces occur, too. Field layer resembles the previous forest types, but some grass species (i.e. Calamagrostis arundinacea, Milium effusum and Melica nutans) are locally common (herb-rich type), and Vaccinium myrtillus and Sphagnum species are present in swampy localities (myrtilloso-sphagnosum-type) $(\mathbf{3}, \mathbf{4})$. Average age of trees is $80-120$ years.

Old-growth fir-spruce forests represent the "southern taiga" communities in the strict sense (Shirokov 1998). Tree stand consists of spruce, linden and fir (Abies sibirica). Average age of coniferous trees is 180-220 years. The species dominating in underbrush are Euonymus verrucosa, Lonicera xylosteum, Daphne mezereum and shrub-sized maple. Field layer is composed by both hemiboreal (Aegopodium podagraria, Viola mirabilis, Asarum europeum, Pulmonaria obscura, Stellaria holostea) and boreal (Dryopteris austriaca, D. cartusiana, Oxalis acetosella, Actaea erythrocarpa, Cinna latifolia, Circaea alpina) herbaceous species. Most of the communities belong to the plant association Tilieto-Abiegneto-Piceetum dryopteridoso-aegopodioso-oxalidosum $(\mathbf{1 2}, \mathbf{1 3}, \mathbf{1 4}, \mathbf{1 5}$, 16, 17, 18, 20) (Shirokov 1998).

Old-growth pine forests $(11,19)$ occur mostly on sandy soils. Pine dominates, very rarely accompanied by spruce, birch and aspen. Shrubby Vaccinium myrtillus and V. uliginosum, and drought-tolerant mosses (Hylocomium splendens etc.) cover the ground. Average age of coniferous trees is $120-150$ years.

\section{Discussion}

Junghuhnia vitellina Spirin, spec. nova - Fig. 2

Basidiomata effuso-reflexa vel effusa, aurantioflava ad vitellina, coriacea. Porae angulatae vel fissile, 2-3 per mm. Systema hypharum dimiticum. Skeletocystidia incrustata adsunt. Sporae inamyloideae, 3.6-4.4 × 1.9-2.2 $\mu \mathrm{m}$.

Holotype: Russia, Primorye Reg., Kedrovaya Pad' Res., Betula mandshurica, 2.XI.1944 L. Vasilyeva (LE 26533, isotype in H).

Basidiocarps annual or most possibly biennial, effused-reflexed to almost resupinate, 5-15 $\mathrm{mm}$ wide, 2-6 $\mathrm{mm}$ thick at base, projecting 3-15 $\mathrm{mm}$. Upper surface pale yellowish to strawcoloured, with few indistinct reddish-brownish zones, slightly pubescent. Edge of pileus very sharp, fairly thin, even or only slightly undulate, concolorous with upper surface. Lower surface vitelline to orange, pores angular or lacerate in resupinate parts, $2-3$ per $\mathrm{mm}$; dissepiments at first relatively thick, then becoming thinner. Section: context pale yellowish, duplex, consisting of upper soft and lower dense layers, with thin dark-brown line between them, $0.5-1 \mathrm{~mm}$ thick, tube layer pale yellowish to vitelline, not stratified, fibrous-coriaceous and slightly agglutinated in young specimens, corky in older ones.

Hyphal structure dimitic. Skeletal hyphae dominating in all parts of basidiocarps, fairly tightly interwoven, subsolid, sometimes irregularly inflated and then with expanded lumen, 3-7 $\mu \mathrm{m}$ wide, pale yellowish in $\mathrm{KOH}$, inamyloid, cyanophilous. Generative hyphae mostly seen in subhymenium, thin- to slightly thickwalled, regularly clamped, of equal thickness, 2.5-5 $\mu \mathrm{m}$ wide. Skeletocystidia deep-rooting and penetrating in the hymenium, thick-walled, clavate or bottle-shaped, irregularly inflated, scanty or moderately encrusted, $35-70 \times 6-10$ $\mu \mathrm{m}$. Cystidioles frequent, $15-18 \times 3-4 \mu \mathrm{m}$. Basidia clavate, four-spored, clamped at the base, $14-17(-20) \times 3.5-4.5 \mu \mathrm{m}$. Basidiospores beanshaped to cylindrical with blunt ends, (3.3-) 3.6-4.4(-4.9) × (1.8-)1.9-2.2(-2.3) $\mu \mathrm{m}$, thinwalled, sometimes with a few small oil-drops, IKI-, CB-.

Causes white rot of wood (Betula mandshurica). Now known only from type locality.

The general habit of Junghuhnia vitellina is reminiscent of Diplomitoporus flavescens (Bres.) Domański, which has paler (pale yel-

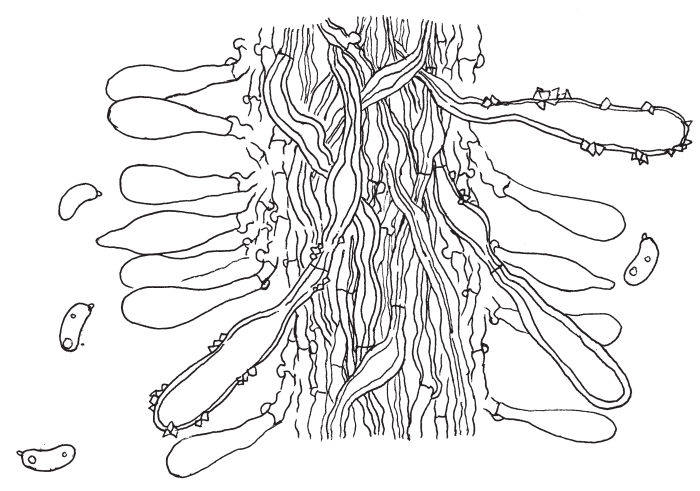

Fig. 2. Junghuhnia vitellina (LE 26533). Hymenium and spores. Scale bar $5 \mu \mathrm{m}$. 
low) pore surface, and lacks skeletocystidia. The spores and basidia of $D$. flavescens are distinctly larger, and its main substrate genus is Pinus. Other orange- or yellow-coloured small-sized polypores are known from Russian Far East: Antrodiella aurantilaeta (Corner) Hattori \& Ryvarden, J. brownii (Humb.) Niemelä, and Postia pileata (Parmasto) Dai \& Renvall. The first one differs in having smaller spores; it also lacks skeletocystidia (Dai \& Niemelä 1997). The spores of J. brownii are smaller, too; it has only $8-10$ pores per $\mathrm{mm}$, and its context becomes red in $\mathrm{KOH}$ (Ryvarden \& Gilbertson 1993). Postia pileata (= Postia amylocystis Dai \& Renvall) is monomitic with soft and fragile basidiocarps, like the species of Auriporia Ryvarden (Parmasto 1980; Dai \& Renvall 1994; Ryvarden \& Gilbertson 1993).

Recently Kotiranta and Saarenoksa (2002) proposed a wider concept of the genus Irpex, including Junghuhnia, Flaviporus, and Steccherinum. However, this taxonomic solution is not supported by molecular data: the type species of Irpex - I. lacteus (Fr. : Fr.) Fr. - comes close to some monomitic polyporoid (Bjerkandera, Ceriporiopsis aneirina) and corticioid (Phlebia and Phanerochaete) fungi (De Koker et al. 2003, Greslebin et al. 2004), whereas the Junghuhnia and Steccherinum species belong to another clade together with Antrodiella (Johannesson et al. 2000, Binder et al. 2005). So I address the new species to the genus Junghuhnia Corda.

Cinereomyces Jülich, Bibl. Mycol. 85:

396, 1982.

The genus was described by Jülich (1982) with Polyporus lindbladii Berk. as a type and the sole species. The reason of describing this genus was the dissolving of the skeletal hyphae in $\mathrm{KOH}$ and their slightly amyloid reaction. Gilbertson and Ryvarden (1985) included both Polyporus lindbladii and Physisporus lenis P. Karst. in Diplomitoporus. Niemelä (in Renvall et al. 1991) transferred the latter in Skeletocutis, since it is characterized by white rot, dimitic hyphal system, fusiform cystidioles, and it has cylindrical and curved spores. The main differences distinguishing $S$. lenis from the core of Skeletocutis are soft-corky consistence of the basidiocarps and evident lack of gelatinization and absence of the characteristic thorn-like encrustations at the dissepiment edges. The crystalline agglomerations in the subiculum and hymenium of $S$. lenis and $S$. vulgaris (illustrated in Niemelä \& Dai 1997) are of a spherical type. However, the spore shape of $S$. lenis resembles not only some Skeletocutis species, but also the type species of Cinereomyces, i.e. C. lindbladii (Berk.) Jülich. Cystidioles of this species and $S$. lenis are distinctly fusoid, while they are conical in other Diplomitoporus species (D. crustulinus (Bres.) Domański and D. flavescens). Hyphae of C. lindbladii and S. lenis are of the same size, and skeletals swell in $\mathrm{KOH}$. So, there are reasons to include $S$. lenis and its closest relative $S$. vulgaris in Cinereomyces.

Two other species, Skeletocutis alutacea and S. subvulgaris Y.C. Dai share the soft-corky, non-gelatinized basidiomata with the $S$. lenis complex. However, they have typical Skeletocutis-like hyphae at the dissepiment edges (Keller 1979, Dai 1998), and undoubtedly belong to this genus.

Cinereomyces lenis (P. Karst. in Rabenh. \& Winter) Spirin, comb. nova

Basionym: Physisporus lenis P. Karst. in Rabenh. \& Winter, Fungi Exs. Europ. Extraeurop. 16: 3527, 1886 (holotype in H, studied).

Skeletocutis lenis (P. Karst. in Rabenhorst \& Winter) Niemelä in Renvall et al., 1991.

For a description, see Niemelä \& Dai (1997).

Distribution and ecology. This species is extremely rare in the study area, found only once on very rotten pine trunk in old pine forest (11). As noted by Finnish authors (Renvall et al. 1991, Niemelä \& Dai 1997), pine is certainly the favourite substrate in North Europe. Niemelä et al. (2002) considered C. lenis a so-called kelo fungus-a species that favours long-ago died, finally fallen pine trees.

Specimens examined: Russia. Nizhny Novgorod Reg., Semyonov Dist., Kerzhensky Res., Pinus sylvestris, 24.IX.1998 Spirin (LE 212400). - Finland. Etelä-Häme, Lammi, Kotinen Virgin Forest, Picea abies, 11.IX.2001 Spirin \& Kosolapov (LE).

Cinereomyces vulgaris (Fr.) Spirin, comb. nova

Basionym: Polyporus vulgaris Fr., Syst. Mycol. 1: $381,1821$. 
Skeletocutis vulgaris (Fr.) Niemelä \& Y.C. Dai, 1997.

Lectotype: Sweden. Femsjö (UPS, not studied - see description in Niemelä \& Dai 1997).

Basidiocarps short-living, resupinate, softcorky, up to $20 \mathrm{~cm}$ wide. Pore surface at first white, later creamy, with ochraceous tint when dry or overwintered, pores round, small, 6-8 per $\mathrm{mm}$, with thin entire dissepiment edges. Margin initially fibrillose, later pores extends to the very edge. Section: context whitish, often very thin (up to $0.5 \mathrm{~mm}$ thick), soft corky, tubes concolorous, up to $2.5 \mathrm{~mm}$ thick.

Hyphal structure dimitic. Skeletals thickwalled, rarely branched at the right angle, with lumina of varying size, 2-2.8 $\mu \mathrm{m}$ wide, IKI-, $\mathrm{CB}-$, unchanging in $\mathrm{KOH}$, randomly arranged in tube trama. Generative hyphae present mostly in subhymenium and at dissepiment edges (and there with apices swollen up to $5 \mu \mathrm{m}$ wide), thinwalled, with regular clamps, $1.5-2 \mu \mathrm{m}$ wide. Star-like crystals occasionally present. Cystidioles bottle-shaped to hyphoid, swollen at the base, $6-12 \times 3-5 \mu \mathrm{m}$. Basidia ovoid or barrelshaped, $6-10 \times 4-6 \mu \mathrm{m}$. Basidiospores (2.6-) $2.8-3.8(-4.3) \times(0.8-) 0.9-1.5 \mu \mathrm{m}$, narrowly cylindrical, moderately curved, thin-walled, rarely with small guttules.

New to Russia. Basidiocarps of $C$. vulgaris from the study area evidently hibernate, and are probably biennial.

Distribution and ecology. This species is not rare in the study area. Niemelä and Dai (1997) noted that Cinereomyces lenis and C. vulgaris are characterized by rather different ecological preferences. While the first one is a so-called kelo species occurring mostly in virgin forests, the latter has relatively wide ecological amplitude. C. vulgaris was collected six times in the study area: in spruce forests and thinned mixed forests $(6,18)$; one collection was made from fir trunk at the edge of an inundated forest (16). Lositskaya (1998) noted 'C. lenis' to grow on wood of Quercus robur in Pskov Region (NorthWest Russia); her specimen is in fact $C$. vulgaris. That is the northernmost locality known so far in European Russia.

Specimens examined: Russia. Nizhny Novgorod Reg., Arzamas Dist., Pustynsky Res., Picea abies, with Fomitopsis pinicola and Sistotrema resinicystydium, 7.VII.1999 and 11.VII.2000 Spirin (LE 211381, LE 212398); Sharanga Dist., Kilemarsky Res., P. abies, 17.VIII.2004 Spirin
2139, 2140, 2170 (H). Uren' Dist., Vaya, Abies sibirica, with Henningsomyces candidus, 27.V.2000 Spirin (LE 213350). Pskov Reg., Gdov Dist., Chernyovo, Quercus robur, 6.XI.1996 Lositskaya (LE 201202).

\section{Skeletocutis Kotl. \& Pouzar, Česká Mykol.} 6: 103,1958

Here this genus is restricted to exclude the S. lenis complex. Macroscopically Skeletocutis is characterized by resupinate to effused-reflexed or pileate basidiocarps with more or less agglutinated hymenium, and gelatinous basal layer of the subiculum. Hyphal system is mono- to trimitic; generative hyphae are encrusted by spiny crystals at the dissepiment edges. Basidia are short-clavate to barrel-shaped, $8-15 \times 4-5 \mu \mathrm{m}$; cystidioles not infrequent, bottle-shaped to conical. Spores allantoid, cylindrical to ellipsoid, of various size, IKI- and CB-. The species cause a white rot.

The genus Gelatoporia Niemelä seems to be closely related to Skeletocutis. Light-coloured, hygrophanous and more or less gelatinized basidiocarps, narrowly clavate basidia and cylindrical spores belong to the common features. The dissepimental hyphae of G. subvermispora (Pilát) Niemelä bear crystalline encrustations, which at first sight remind those of Skeletocutis, but their identity is not confirmed by SEM (Niemelä 1985a). So, there is a reason to keep these genera separate, despite of their high similarity.

The presence of monomitic species in Skeletocutis makes the delimitation from Gelatoporia and Ceriporiopsis Domański slightly unclear. Ryvarden \& Gilbertson (1994) combined three species of Skeletocutis - S. azorica (D.A. Reid) David, S. jelicii Tortić \& David, and S. portcrosensis David - into Ceriporiopsis, and considered the miticity to be the principal difference between these two genera. Niemelä (1998) casts doubts on this solution, since the existence of Skeletocutis species with very few skeletals $(S$. albocremea David, $S$. borealis Niemelä, S. friata Niemelä \& Saarenoksa) obscures this delimitation. While $S$. alutacea is a dimitic counterpart of S. azorica (Ryvarden \& Gilbertson 1994), and $S$. friata of $S$. portcrosensis (Niemelä 1998), the third monomitic species, $S$. jelicii, seems to be more distant from the other Skeletocutis species because of its ellipsoid spores. Ryvarden \& Gilbertson (1994) used this feature as a reason to transfer it to Ceriporiopsis. 
Skeletocutis albocremea David, Naturaliste Canadien 109: 237, 1982. - Fig. 3

Basidiocarps small, annual, resupinate, waxy when fresh, soft when dry, very thin (up to 0.5 $\mathrm{mm}$ thick). Pore surface initially white, then creamy, even, pores angular, 6- 8 per $\mathrm{mm}$, with very thin entire dissepiments. Margin very thin, byssoid, with minute rhizomorphs, white, up to $1 \mathrm{~mm}$ wide. Section: context indistinct, tubes short, cream-coloured.

Hyphal structure dimitic. Skeletals very few, 3-3.5 $\mu \mathrm{m}$ wide, thick-walled, with narrow lumina, strongly swelling and dissolving in $\mathrm{KOH}$. Generative hyphae dominating in basidiocarp, 3-4 $\mu \mathrm{m}$ wide, clamped, thin-walled, at the dissepiment edges spirally coiled and encrusted. Cystidioles bottle-shaped or conical, 10-12 $\times$ 3.5-5 $\mu \mathrm{m}$. Basidia short clavate, 10-14 × 4-5 $\mu \mathrm{m}$, four-spored, with basal clamp. Basidiospores (3.8-)4.2-5(-5.2) × (1-)1.2-1.7(-1.8) $\mu \mathrm{m}$, cylindrical, slightly curved, often with guttules.

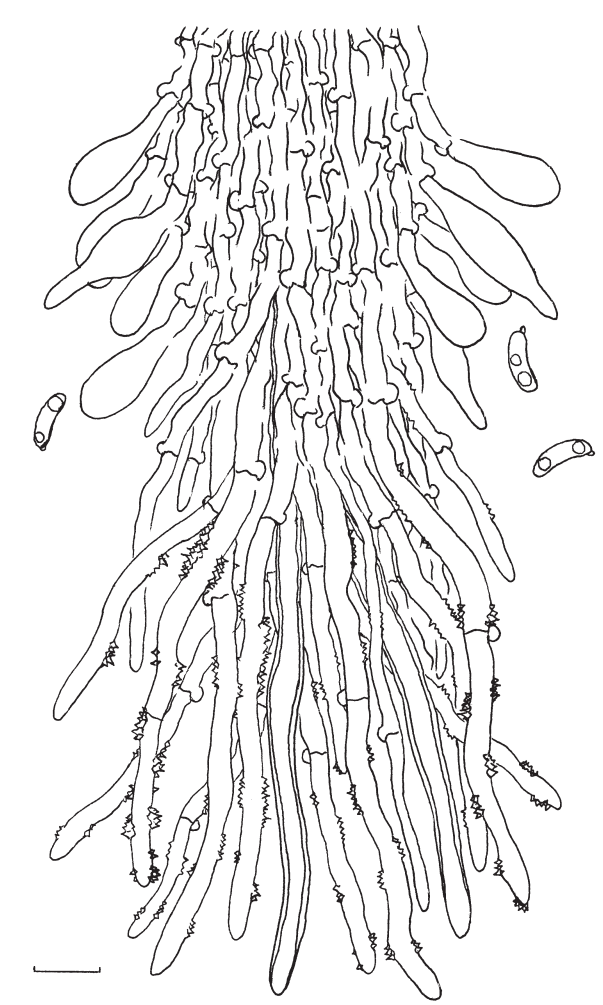

Fig. 3. Skeletocutis albocremea (LE 213386). Hymenium and spores. Scale bar $5 \mu \mathrm{m}$.
The species is close to $S$. papyracea, which has thicker basidiocarps, thin but distinct subiculum, larger pores, and more abundant skeletal hyphae in the tube trama. As was noted by Niemelä (1998), the habit of fruitbodies resembles an initial stage of $S$. biguttulata, whose spores are longer and skeletals stay unchanged in $\mathrm{KOH}$.

Distribution and ecology. In Russia collected only once from rotten trunk of pine in old pine forest (5). Probably it is a southern species. Recently reported as new to Russia (Spirin 2004).

Specimens examined: Russia. Nizhny Novgorod Reg., Lukoyanov Dist., Panzelka, Pinus sylvestris, 1.VIII.1998 Spirin (LE 213386).

Skeletocutis alutacea (Lowe) Jean Keller, Persoonia 10: 353, 1979. - Fig. 4

Basidiocarps annual, resupinate, about $1 \mathrm{~mm}$ thick. Pore surface creamy-white to pale yellow, pores round to angular, (4-) 5-8 (-9) per mm, with thin entire dissepiments. Margin fimbriate to floccose, white, with thin $(0.1-0.5 \mathrm{~mm}$ wide) well developed rhizomorphs, partly indistinct and then pores reach the edge of the fruitbody. Section: context very thin, floccose, whitish, tube layer soft-corky, concolorous with margin and context.

Hyphal structure dimitic. Skeletal hyphae thick-walled, with distinct lumina, present in all parts of the basidiocarp, penetrating into dissepiment edges and encrusted there, 2.5-4.5 $\mu \mathrm{m}$ wide, unchanged in $\mathrm{KOH}$ and IKI. Generative hyphae thin- to moderately thick-walled, clamped, 3-4.5 $\mu \mathrm{m}$ wide, encrusted at the dissepiment edges. Cystidioles conical to fusoid, 10-14 $\times 4-5 \mu \mathrm{m}$. Basidia $10-13 \times 4-5 \mu \mathrm{m}$, basally clamped. Basidiospores $(2.8-) 3-4.1(-4.3) \times(1.5-) 1.7-2 \mu \mathrm{m}$, cylindrical, slightly curved, with occasional guttules.

The species has a characteristic habit (presence of well developed rhizomorphs) and anatomy (both generative and skeletal hyphae are encrusted at the dissepiment edges). An apical encrustation on skeletal hyphae is very rare in subgenus Incrustoporia and can be used for identification of this species.

Distribution and ecology. Collected in the study area only once from decorticated trunk of Picea abies in old spruce forest (3). Other Skeletocutis species (S. brevispora and S. odora) were collected in the neighbourhood. Skeletocutis al- 


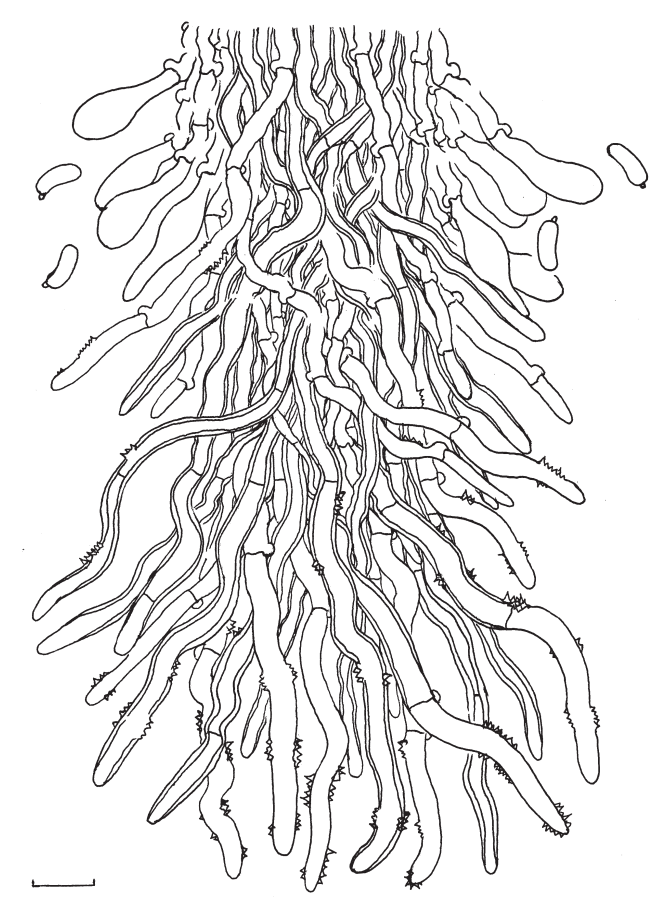

Fig.4. Skeletocutis alutacea (LE 208266). Hymenium and spores. Scale bar $5 \mu \mathrm{m}$.

utacea is evidently rare, and special substrate and ecological preferences remain unknown. Ryvarden and Gilbertson (1994) mentioned Pinus, Acer, Fagus and Salix as the substrates; Niemelä (1998) listed Fagus and Carpinus. Ryvarden et al. (2003) mentioned three Norwegian records from wood of Pinus sylvestris. Now Picea and Betula could be added to the list of its substrates, too. Spirin (2000) and Spirin \& Shirokov (2002) reported this first time from Russia.

Specimens examined: Russia. Nizhny Novgorod Reg., Lukoyanov Dist., Razino, Picea abies, 5.VIII.1998 Spirin (LE 208266). Karelian Rep., Medvezhyegorsk Dist., Maslozero, Betula pubescens, 17.VIII.2000 Lositskaya (LE 210019).

Skeletocutis biguttulata (Romell) Niemelä, Acta Bot. Fennica 161: 5, 1998.

For a description, see Niemelä (1998).

Distribution and ecology. Uncommon, but not rare in the study area. Abundant collections of this species were made in the Klenovik Reserve (15), where it is very common on fallen trunks of Abies sibirica and adjacent debris (fallen leaves).
Probably this tree is the main substrate in continental areas of Russia. In southern part of the study area the species was found only once, on very rotten trunk of spruce in old herb-rich aspen forest (Tilieto-Tremuletum aegopodioso-magnoherbosum) (4).

Specimens examined: Russia. Nizhny Novgorod Reg., Vetluga Dist., Klenovik Res., Abies sibirica, 11.VIII.1999 Spirin (LE 208959, LE 212660); Lukoyanov Dist., Razino, Picea abies, with Mucronella calva, 17.IX.1999 Spirin (LE 212113).

Skeletocutis brevispora Niemelä, Acta Bot. Fennica 161: 10, 1998.

Basidiocarps annual, resupinate, waxy when fresh, firm-ceraceous after drying, 1-2 mm thick. Pore surface at first white, later straw- to lemonyellowish, pores at first 6-8 (-9) per mm, round to angular, in mature fruitbodies 4-5 per mm, lacerate; dissepiments thin, entire, without any pruina. Margin initially pruinose-byssoid, with small growing tubes, white, later pale straw-coloured or yellowish. Section: context very thin, white, often emerging from underlying dead basidiocarps of Phellinidium ferrugineofuscum, tube layer translucent, concolorous with pore surface.

Hyphal structure dimitic. Skeletals thickwalled, dominating in all parts of basidiocarps, with distinct lumina, 3-4 $\mu \mathrm{m}$ wide, swelling up to $6 \mu \mathrm{m}$ wide in $\mathrm{KOH}$ (reaction sometimes indistinct in young fruitbodies), penetrating into dissepiment edges. Generative hyphae mostly thinwalled, with relatively large clamps, 3-3.5 $\mu \mathrm{m}$ wide, at the dissepiment edges poorly encrusted. Cystidioles bottle-shaped, often with sharp apices, $10-13.5 \times 4.5-5.5 \mu \mathrm{m}$. Basidia short-clavate, $9-12 \times 4-4.5 \mu \mathrm{m}$, basally clamped. Basidiospores (3.2-)3.4-4.2(-4.6) × (1-)1.2-1.6(-1.7) $\mu \mathrm{m}$, moderately curved, tapering to the apiculus, without guttules.

Niemelä (1998) noted that the occurrence of $S$. brevispora on dead Phellinidium ferrugineofuscum is so frequent and regular that it can be used for identification. Moreover, the species is characterized by some anatomical features: skeletals are distinctly swelling (albeit not dissolving) in $\mathrm{KOH}$, and spores are short, curved, and aguttulate.

Distribution and ecology. In the description (Niemelä 1998) the species was reported 
from Finland and Sweden. Later it was found in Russian Karelia (Lindgren 2001, Niemelä et al. 2001), north-eastern China (Dai 2000) and Norway (Ryvarden et al. 2003). Niemelä (2001) considered this species to be mostly rare, but locally common. Similar situation is observed in the study area. In northern old taiga forests $S$. brevispora is evidently rare $(\mathbf{1 5}, \mathbf{1 8})$. However, in southern part of the area $(3,4)$ this species was collected regularly, not only in old spruce forests, but also in swampy birch type (Betuleta myrtilloso-sphagnosa) forests, where solitary fallen spruce trunks are occupied by its predecessor $P$. ferrugineofuscum. A small polypore Oligoporus floriformis (Quél.) Gilb. \& Ryvarden was fruiting abundantly on these trunks, too.

Specimens examined: Russia. Nizhny Novgorod Reg., Vetluga Dist., Klenovik Res., Picea abies, together with Phellinidium ferrugineofuscum, 11.VIII.1999 Spirin (LE 212250); Lukoyanov Dist., Razino, dead P. ferrugineofuscum on P. abies, 5.VIII.1998 and 16.VII.1999 Spirin (LE 208439; LE 212684; LE 212399; LE 208497, LE 212253); Sharanga Dist., Kilemarsky Res., P. abies, with P. ferrugineofuscum, 26.IX.1999 Spirin (LE 212396). Finland. Pohjois-Karjala, Ilomantsi, dead P. ferrugineofuscum on P. abies, 25.VIII.1995 Lositskaya (LE 208992).

Skeletocutis carneogrisea David, Naturaliste Canadien 109: 246, 1982.

The species was described by David (1982); Jahn (1983) and Niemelä (1985a) discussed its ecology.

Distribution and ecology. Collected from coniferous wood and dead basidiocarps of Trichaptum abietinum (Dicks. : Fr.) Ryvarden (5, 6). Skeletocutis carneogrisea is evidently not rare in the study area, distributed in both old-growth and suburban forests. Once the species was found near Nizhny Novgorod City; it was growing on moribund young spruce decayed by Trichaptum abietinum.

Specimens examined: Russia. Nizhny Novgorod Reg., Arzamas Dist., Pustynsky Res., dead Trichaptum abietinum on Pinus sylvestris, 1.VII.2000 Spirin (LE 213650); Bogorodsk Dist., Picea abies, 18.VIII.1998 Spirin (LE 212389); Lukojanov Dist., Panzelka, Pinus sylvestris, with Trichaptum abietinum and Skeletocutis papyracea, 4.VIII.2000 Spirin (LE 213019). Finland. Etelä-Häme: Lammi, dead Trichaptum abietinum on Picea abies, 4.IX.1986 Niemelä 3557 (H, dupl. in LE).
Skeletocutis chrysella Niemelä, Acta Bot. Fennica 161: 13, 1998.

For a description, see Niemelä (1998).

This species differs from the closest relative S. stellae by short-living basidiocarps and abundant binding hyphae in the context. The change of colour is also characteristic: stains on pore surface are honey-yellowish in S. chrysella and reddish-brown in S. stellae. The latter has abrupt opaque margin.

Distribution and ecology. An extremely rare species, found only once in the study area on strongly decayed corticated spruce trunk killed by Porodaedalea chrysoloma (Fr.) Fiasson \& Niemelä in very old spruce-fir forest (17). It grows together with Fomitopsis pinicola (Sw. : Fr.) P. Karst., Trichaptum abietinum and still unnamed species of Oxyporus corticola complex.

Specimen examined. Russia. Nizhny Novgorod Reg., Tonkino Dist., Tonkinsky Res., Picea abies, 21.VIII.2000 Spirin (LE 210132).

Skeletocutis kuehneri David, Naturaliste Canadien 109: 248, 1982.

For descriptions, see David (1982) and Niemelä (1998).

Distribution and ecology. Not rare in the study area, collected in coniferous (mostly spruce) forests $(5,6,12,15,17,18,19)$ from decorticated trunks of various size, often together with Trichaptum abietinum. Two times S. kuehneri was observed on fallen spruce logs without signs of Trichaptum species, in associations with other aphyllophoroid fungi: Amylocorticium subincarnatum (Peck) Pouzar, Fomitopsis rosea (Alb. \& Schwein. : Fr.) P. Karst., Antrodia serialis (Fr.) Donk, Serpula himantioides (Fr. : Fr.) P. Karst., and Porotheleum fimbriatum (Pers. : Fr.) Fr.

Specimens examined: Russia. Nizhny Novgorod Reg., Arzamas Dist., Pustynsky Res., Picea abies, 2.VII. \& 22.VII.2000 Spirin (LE 213632, LE 212624); Vetluga Dist., Klenovik Res., P. abies, 8.VIII.1999 Spirin (LE 211386); Kovernino Dist., Belbazh, P. abies, 27.VIII.2000 Spirin (LE 213654); Lukoyanov Dist., Panzelka, P. abies, 3.VIII.2004 Spirin 2073 (H); Sharanga Dist., Kilemarsky Res., P. abies, 18.VIII.2004 Spirin 2183 (H); Tonkino district, Tonkinsky Res., Abies sibirica, 1.VI.2000 Spirin (LE 210870); Tonshaevo Dist., Pizhemsky Res., Pinus sylvestris, 29.V.2000 Spirin (LE 212626). Gorno-Altai Reg., Kaitanak, P. sibirica, 3.VIII.1968 Bondartseva (LE 26456). Leningrad Reg., Vsevolozhsk Distr., Korosary, 
P. abies, 1.IX.2001 Zmitrovich \& Spirin (LE 212269, LE 212270). Krasnodar Reg., Caucasian Res., Abies alba, 3.VIII.1936 Vasilyeva (LE 26440). Belarus. Bialoviezha Virgin Forest, Korolevo-Mostovskoye, Pinus sylvestris, 22.VIII.1966 Bondartseva (LE 26445) (new to Belarus). Finland. Pohjois-Karjala, Ilomantsi, Picea abies, 24.IX.1997 Lositskaya (LE 208975).

Skeletocutis odora (Sacc.) Ginns, Mycotaxon 21: 332, 1984.

For a description, see Niemelä (1998).

Distribution and ecology. Skeletocutis odora is very common in aspen forests in southern part of the area $(3,4,5)$ near brooks or small rivers. Twice $S$. odora was observed on thick fallen spruce logs in exposed forest edge; it was fruiting solitarily, without associations with other fungi. In spruce forests, both in southern and northern $(3,6,15,18)$ parts of area, the species is common on fallen, mostly corticated spruce trunks, and grows preferably in association with Fomitopsis rosea, Crustoderma dryinum (Berk. \& M.A. Curtis) Parmasto, Leptoporus mollis (Pers. : Fr.) Quél. and Phlebia centrifuga P. Karst. (Spirin \& Shirokov 2002). Similar preferences were noted by Finnish authors (Kotiranta \& Niemelä 1981, Renvall et al. 1991). One collection is from dead basidiocarp of Phlebia centrifuga (LE 211400).

Specimens examined: Russia. Nizhny Novgorod Reg., Arzamas Dist., Pustynsky Res., Picea abies, 8.VII.1999 Spirin (LE 213342); Vetluga Dist., Klenovik Res., $P$. abies, 13.VIII.1999 Spirin (LE 212376); Lukoyanov Dist., Razino, P. abies, 22.VII.1997 and 5.VIII.1998, dead Phlebia centrifuga on P. abies, 4.VIII.1999, Populus tremula, 1.VIII and 17.IX.1999 Spirin (LE 212386, LE 211400, LE 212387, LE 212394, LE 213017); Panzelka, Picea abies, 1.VIII.1998 Spirin (LE 213341), Populus tremula, 3.VIII.2004 Spirin 2057 (H); Sharanga Dist., Kilemarsky Res., Picea abies, 26-27.IX.1999 Spirin (LE 212380, LE 213364).

Skeletocutis papyracea David, Naturaliste Canadien 109: 254, 1982.

For a description, see Niemelä (1998).

There are problems in taxonomy of the $S$. papyracea-S. subincarnata complex. The two species are characterized by distinct reaction of skeletals in $\mathrm{KOH}$. In my opinion, it is very difficult to affirm in practice, whether skeletal hyphae become translucent and jelly-like or dissolve and become invisible. The reaction is very variable in microscopic mounts between specimens collected in different seasons even from the same substrate.
Now it seems that these species can be separated from each other only by the shape and size of basidia and spores, and by different ecology.

Distribution and ecology. The species is widely distributed in coniferous forests of the area (3, $5,8,9,11,18$ ). It was collected in both managed forests and forest reserves. The fruitbodies emerge in July-August commonly, and persist about one month.

Specimens examined: Russia. Nizhny Novgorod Reg., Bor Dist., Kerzhensky Res., Picea abies, 24.IX.1998 Spirin (LE 212391); Lukoyanov Dist., Panzelka, Pinus sylvestris, 22.VII.1999, 4.VIII.2000 \& 6.X.2001 Spirin (LE 210036; LE 213347; LE 213377; LE 211361), Razino, P. sylvestris, 8.VIII.1998 Spirin (LE 212393); Semyonov Dist., Kerzhensky Res., P. sylvestris, 27.IX.1998 Spirin (LE 212397); Sharanga Dist., Kilemarsky Res., P. abies, 28.IX.1999 Spirin (LE 212395). Leningrad Reg., Tosno Dist., Lisino, P. abies, 19.IX.1960 Bondartseva (LE 26471). Mordovia, Mordovsky Res., P. sylvestris, 1923.VIII.1937 Nikolayeva (LE 26446, LE 26477). Belarus. Bialoviezha Virgin Forest, Korolevo-Mostovskoye, P. abies, 9.IX.1966 Bondartseva (LE 26523) (new to Belarus). Estonia. Saaremaa, P. abies, 11.IX.1953 Parmasto (LE 26401); Viljandi, P. abies, 19.VIII.1953 Parmasto (LE 26437). Finland. Etelä-Häme, Lammi, P. sylvestris, 11.IX.2001 Spirin \& Kosolapov (LE).

Skeletocutis stellae (Pilát) Jean Keller, Persoonia 10: 353, 1979.

The species is well described and illustrated by Eriksson (1958) and Niemelä (1998).

After a study of material from the Nizhny Novgorod Region, some new features could be supplied here. One specimen of $S$. stellae (LE 208486) was collected from dead basidiocarps of Fomitopsis pinicola and Porodaedalea chrysoloma. Renvall (1995) mentioned two collections of $S$. stellae from spruce trunks, strongly decomposed by $P$. chrysoloma. Niemelä (1998) noted the growth on dead basidiocarps of $P$. chrysolo$m a$ to be typical for $S$. chrysella, but occasionally both the sibling species share this ecology. So the critical differences are the size of pores (7-10 per $\mathrm{mm}$ in S. stellae vs. 4-6 per $\mathrm{mm}$ in S. chrysella), the changing of colour of $S$. chrysella during drying, and more abundant binding hyphae in its context; the spores are almost identical.

Swelling of skeletal hyphae with $\mathrm{KOH}$ seems to be an essential feature of the "medium-thickspored group" of Skeletocutis species (S. subincarnata and its satellites, Niemelä 1998), though it was not emphasized specially. However, this 
phenomenon was observed also in the "narrowspored group": a ten-layered fruitbody of S. stellae (LE 210070) was collected in late spring; its lower tube layer was overgrown by mycelium with abundant skeletals, which swelled and dissolved in $\mathrm{KOH}$ like those of $S$. papyracea.

Distribution and ecology. Evidently rare species in the area; all specimens were found in very old taiga forests $(\mathbf{1 8 , 2 0})$ on fallen spruce trunks at late stages of wood decomposition. Average diameter of the trunks was $50-60 \mathrm{~cm}$. In Finland S. stellae is classified as a species of both spruceand pine-dominated virgin forests (Kotiranta \& Niemelä 1996, Lindgren 2001). Fomitopsis pinicola and, probably, Porodaedalea chrysoloma could be regarded as possible predecessors. The rare Boreostereum radiatum (Peck) Parmasto, Columnocystis ambigua (Peck) Pouzar, Fomitopsis cajanderi (P. Karst.) Kotl. \& Pouzar, and Phellinidium sulphurascens (Pilát) Y.C. Dai grew in the neighbourhood-all they prefer boreal continental coniferous forests (taiga) and are mostly unknown in West Europe.

Specimens examined. Russia. Nizhny Novgorod Region, Tonshaevo Dist., Burepolom, Picea abies, 28.V.2000 Spirin (LE 210070); Sharanga Dist., Kilemarsky Res., dead Fomitopsis pinicola and Porodaedalea chrysoloma on P. abies, 28.IX.1999 Spirin (LE 208486), P. abies, with Repetobasidium mirificum, 28.IX.1999 Spirin (LE 208962), P. abies, 22.VIII.2004 Spirin 2274 (H). Belarus. Bialoviezha Virgin Forest, Pinus sylvestris, 27.VIII.1966 Bondartseva \& Parmasto (LE 25825).

\section{Skeletocutis subincarnata (Peck) Jean Keller, Persoonia 10: 353, 1979.}

Basidiocarps annual, resupinate, cartilaginous when fresh, soft-coriaceous after drying, 1-2 $\mathrm{mm}$ thick. Pore surface cream with vinaceous tint, even or nodulose on sloping substrate, pores angular, with thin entire dissepiments without pruina, in some cases lacerate, (4-) 5-7 per mm. Margin mostly well visible and sharply delimited, entire, up to $1 \mathrm{~mm}$ wide, often white or pale cream, in mature basidiocarps paler than pore surface, without rhizomorphs. Section: context cream-coloured, often well developed, up to 1 $\mathrm{mm}$ thick, tube layer concolorous with pore surface, up to $1 \mathrm{~mm}$ thick.

Hyphal structure dimitic. Skeletals thickwalled, present mostly in trama, with narrow lumina, distinctly swelling and partly dissolving in $\mathrm{KOH}, 3-4 \mu \mathrm{m}$ wide; a few ones extending to dis- sepiment edges. Generative hyphae 2-2.8 (-3.5) $\mu \mathrm{m}$ wide, thin-walled, clamped, dominating in subhymenium, straight and encrusted with thorny crystals. Cystidioles conical to subglobose, often sharp pointed, 9-12 × 3-5 $\mu \mathrm{m}$. Basidia barrelshaped to ovoid, $8-9 \times 4-5.5 \mu \mathrm{m}$, clamped at the base. Basidiospores cylindrical, distinctly tapering to the apiculus, hyaline, (3-)3.2-4.6 (-5.2) $\times$ (1-) $1.2-1.8(-2) \mu \mathrm{m}$, usually without guttules.

Distribution and ecology. Rare species in the study area, collected only three times $(\mathbf{1 5}, \mathbf{1 7}$, 18) from strongly decayed, moss-covered, partly corticated trunks of spruce in old moist taiga forests.

Specimens examined: Russia. Nizhny Novgorod Reg., Vetluga Dist., Klenovik Res., Picea abies, 11.VIII.1999 Spirin (LE 212379); Sharanga Dist., Kilemarsky Res., P. abies, 17.VIII.2004 Spirin 2134 (H); Tonkino Dist., Tonkinsky Res., P. abies, 23.VIII.2000 Spirin (LE 210065).

Acknowledgements. I am very grateful to Tuomo Niemelä (University of Helsinki) for his generous help and reviewing of the manuscript. Also I want to thank Ivan Zmitrovich (Komarov Botanical Institute, St.Petersburg) for lengthy taxonomical discussions, important remarks and revision of the Latin.

\section{References}

Averkiev, D.S. 1954: History of the development of vegetation in Gorky Region and its botanical-geographical division [in Russian]. - Trans. Gorky State University 1: 119-136.

Binder, M., Hibbett, D.S., Larsson, K.-H., Larsson, E., Langer, E. \& Langer, G. 2005: The phylogenetic distribution of resupinate forms across the major clades of mushroom-forming fungi. - Systematics and Biodiversity 3: 113-157.

Bondartseva, M.A. 1998: Definitorium fungorum Rossiae. Aphyllophorales 2 [in Russian]. - Nauka, St.Petersburg. $391 \mathrm{pp}$.

Dai, Y.C. 1998: Changbai wood-rotting fungi 9. Three new species and other species in Rigidoporus, Skeletocutis and Wolfiporia (Basidiomycota, Aphyllophorales). - Ann. Bot. Fennici 35: 143-154.

Dai, Y.C. 2000: A checklist of polypores from Northeast China. - Karstenia 40: 23-29.

Dai, Y.C. \& Niemelä, T. 1997: Changbai wood-rotting fungi 6 . Study on Antrodiella, two new species and notes on some other species. - Mycotaxon 64: 67-81.

Dai, Y.C. \& Renvall, P. 1994: Changbai wood-rotting fungi 2. Postia amylocystis (Basidiomycetes), a new polypore species. - Ann. Bot. Fennici 31: 71-76.

David, A. 1982: Étude monographique du genre Skeletocutis (Polyporaceae). - Naturaliste Canadien 109: 235-272. 
De Koker, T., Nakasone, K., Haarhof, J., Burdsall, H. \& Janse, B. 2003: Phylogenetic relationships of the genus Phanerochaete inferred from the internal transcriber spacer region. - Mycol. Res. 107: 1032-1040.

Eriksson, J. 1958: Studies in the Heterobasidiomycetes and Homobasidiomycetes-Aphyllophorales of Muddus National Park in North Sweden. - Symb. Bot. Upsal. 16 (1): 1-172.

Gilbertson, R.L. \& Ryvarden, L. 1985: Some new combinations in the Polyporaceae. - Mycotaxon 20: 362365.

Greslebin, A., Nakasone, K. \& Rajchenberg, M. 2004: Rhizochaete, a new genus of phanerochaetoid fungi. - Mycologia 96: 260-271.

Jahn, H. 1983: Skeletocutis carneogrisea David, ein Doppelgänger von S. amorpha. Funde in Deutschland. - Westfälische Pilzbr. 10-11: 271-277.

Johannesson, H., Renvall, P. \& Stenlid, J. 2000: Taxonomy of Antrodiella inferred from morphological and molecular data. - Mycol. Res. 104: 92-99.

Jülich, W. 1982: Higher taxa of Basidiomycetes. - Bibl. Mycol. 85: 1-485.

Keller, J. 1979: Ultrastructure des hyphes incrustées dans le genre Skeletocutis. - Persoonia 10: 347-355.

Kotiranta, H. \& Niemelä, T. 1981: Composition of the polypore communities of four forest areas in southern Central Finland. - Karstenia 21: 31-48.

Kotiranta, H. \& Niemelä, T. 1996: Threatened polypores in Finland [in Finnish]. - Suomen Ympäristökeskus \& Edita, Helsinki. 184 pp.

Kotiranta, H. \& Penzina, T. 2001: Spongipellis sibirica, comb. nova (Basidiomycetes), and its affinities to the polypore genera Tyromyces, Aurantioporus and Climacocystis. - Ann. Bot. Fennici 38: 201-209.

Kotiranta, H. \& Saarenoksa, R. 2002: New combinations in Irpex (Aphyllophorales, Basidiomycetes). - Polish Bot. Journal 47: 103-107.

Kuznetsov, N.V. (ed.) 1974: The nature of Gorky Region [in Russian]. - Gor'ky, 220 pp.

Lindgren, M. 2001: Polypore (Basidiomycetes) species richness and community structure in natural boreal forests of NW Russian Karelia and adjacent areas in Finland. - Acta Bot. Fennica 170: 1-42.

Lositskaya, V. 1998: On the aphyllophoroid fungi of Pskov Region [in Russian]. - Nov. Syst. Plant. Non Vasc. 33: 90-96.

Niemelä, T. 1985a: On Fennoscandian polypores 9. Gelatoporia n. gen. and Tyromyces canadensis, plus notes on Skeletocutis and Antrodia. - Karstenia 25: 21-40.

Niemelä, T. 1985b: Mycoflora of Poste-de-la-Baleine, northern Québec. Polypores and the Hymenochaetales. - Naturaliste Canadien 112: 445-472.
Niemelä, T. 1998: The Skeletocutis subincarnata complex (Basidiomycetes), a revision. - Acta Bot. Fennica 161: 1-35.

Niemelä, T. 2001: Polypores of Finland and adjacent Russia. - Norrlinia 8: 1-120.

Niemelä, T. \& Dai, Y.C. 1997: Polypore Skeletocutis lenis and its sib S. vulgaris. - Ann. Bot. Fennici 34: 133-140.

Niemelä, T., Renvall, P. \& Penttilä, R. 1995: Interactions of fungi at late stages of wood decomposition. - Ann. Bot. Fennici 32: 141-152.

Niemelä, T., Kinnunen, J., Lindgren, M., Manninen, O., Miettinen, O., Penttilä, R. \& Turunen, O. 2001: Novelties and records of poroid Basidiomycetes in Finland and adjacent Russia. - Karstenia 41: 1-21.

Niemelä, T., Wallenius, T. \& Kotiranta, H. 2002: The kelo tree, a vanishing substrate of specified wood-inhabiting fungi. - Polish Bot. Journal 47: 91-101.

Parmasto, E. 1980: On Auriporia (Aphyllophorales, Polyporaceae). - Mycotaxon 11: 173-176.

Renvall, P. 1995: Community structure and dynamics of wood-rotting Basidiomycetes on decomposing conifer trunks in northern Finland. - Karstenia 35: 1-51.

Renvall, P., Renvall, T. \& Niemelä, T. 1991: Basidiomycetes at the timberline in Lapland 2: An annotated checklist of the polypores of northeastern Finland. - Karstenia 31: 13-28.

Ryvarden, L. 1991: Genera of polypores. Nomenclature and taxonomy. - Synopsis Fungorum 5: 1-364.

Ryvarden, L. \& Gilbertson, R. 1994: European Polypores 2: Meripilus to Tyromyces. - Synopsis Fungorum 7: 388-743.

Ryvarden, L., Stockland, J. \& Larsson, K.-H. 2003: A critical checklist of corticioid and poroid fungi of Norway. - Synopsis Fungorum 17: 1-109.

Shirokov, A. 1998: Structure and dynamics of southerntaiga plant communities in Kilemarsky Reserve.Cand. Biol. thesis [in Russian]. - Nizhny Novgorod. $20 \mathrm{pp}$.

Spirin, W. 2000: Aphyllophoroid fungi in southern-taiga forests of Nizhny Novgorod Region [in Russian]. - Mycology and cryptogamic botany in Russia: traditions and the present time (Materials of conference). St.Petersburg. Pp. 257-258.

Spirin, W. 2004: Aphyllophoroid macromycetes of Reserve "Panzelka pond and pine forests in its surroundings". - Nov. Syst. Plant. Non Vasc. 37: 155-165.

Spirin, W. \& Shirokov, A. 2002: The features of wooddecomposition in virgin fir-spruce forests of Nizhny Novgorod Region. - Mikol. Fitopat. 36 (3): 25-31.

Zmitrovich, I. 2003: Tremelloid, aphyllophoroid and pleurotoid Basidiomycetes of Veps Plateau (Northwest Russia). - Karstenia 43: 13-36. 